\title{
RHETORICAL PRACTICE IN THE CHREIA ELABORATION OF MARA BAR SERAPION
}

\author{
CATHERINE M. CHIN \\ The Catholic University of AMERICA
}

\begin{abstract}
This essay argues that the text known as the Letter of Mara bar Serapion is an example of a Greek rhetorical exercise, the chreia elaboration. The letter fits the paradigm of the chreia elaboration as it is found in Greek rhetorical handbooks, such as those of Theon and Libanius. Since it is a rhetorical exercise, the letter should not be read as straightforward evidence for the experience of Roman conquest in Syria, nor should it be read as evidence for Christian apologetic practice in early Syriac literature. Rather, the letter provides scholars with the opportunity to examine the interaction between Greek rhetorical literature and the rise of Syriac prose literature in late antiquity.
\end{abstract}

The Letter of Mara bar Serapion to bis Son, known through a sixth- or seventh-century manuscript (BM Add. 14658) edited in the nineteenth century by William Cureton, is a little-studied document in scholarship on Syriac literature. ${ }^{1}$ The difficulties involved in

1 William Cureton, Spicilegium Syriacum (London: Francis and John Rivington, 1855), 70-76 (English); 43-48 (Syriac); on the date, see pref. i. I am grateful to Michael Penn and Tina Shepardson for their critical comments and suggestions on an earlier version of this essay. I would also like to thank the anonymous readers for Hugoye for their suggestions, and 
dating the work and determining the religious and philosophical persuasion of its author, in addition to the general lack of philosophical creativity in the text itself, have relegated the letter to a secondary position in the study of early Syriac literature and Syriac Christianity. ${ }^{2}$ There have been strong arguments that the writer was not a Christian, but a Stoic sympathetic to Christianity; ${ }^{3}$ still, the examination of the letter by Kathleen McVey, presented in 1988, has to a certain extent re-opened the question of the author's allegiances. The philosophical themes in the letter are not uniquely Stoic, as McVey points out; ${ }^{4}$ at the same time, the references to Christianity are marginal enough to the general rhetorical arc of the letter to cast doubt on McVey's thesis that the author was a Christian propagandist. ${ }^{5}$ Studies of the letter have in the main concentrated on its philosophical, religious, and historical content, and the relationship between its content and its putative author, rather than on its rhetorical form. A closer examination of the form of the letter may help place it more firmly in its ancient intellectual context, which, I argue, is that of a standard Greek rhetorical exercise, the chreia elaboration. When the text is situated in this rhetorical context, the murkiness of the historiographical questions surrounding the text's date and "religious" character becomes in

Orval Wintermute, who first pointed me in the direction of Mara bar Serapion.

2 There have been very few studies of the letter in the past century. The major bibliography is: Kathleen McVey, "A Fresh Look at the Letter of Mara Bar Serapion to his Son," V. Symposium Syriacum 1988, ed. R. Lavenant, Orientalia Christiana Analecta 236 (1990): 257-72; Friedrich Schulthess, "Der Brief des Mara bar Sarapion," Zeitschrift der deutschen morgenländischen Gesellschaft 51 (1897): 365-91; and the comments of H. J. W. Drijvers in "Hatra, Palmyra und Edessa: Die Städte der syrischmesopotamischen Wüste in politischer, kulturgeschichtlicher und religionsgeschichtlicher Beleuchtung," $A N R W$ II.8 (1977), at 886-87. I very much regret that the most recent article to appear on the letter, Ilaria Ramelli's “La lettera di Mara bar Serapion,” Stylos 13 (2004): 77-104, was unavailable to me at the time of writing and could not be incorporated into this article.

${ }^{3}$ Notably those by F. Schulthess, "Brief," 381-91.

${ }^{4}$ K. McVey, "Fresh Look," 261-62.

${ }^{5}$ K. McVey, "Fresh Look," 270-72; against this view, see F. Millar, The Roman Near East 31 BC-AD 337 (Cambridge: Harvard University Press, 1993), 460-62. 
some ways easier to understand: if the author of the document is not an original Mara bar Serapion, but a later writer composing a prosopopoetic exercise in his name, the vagueness of historical detail in the letter and its relatively commonplace philosophical ideas become the stuff of classroom "general knowledge" rather than documents of individual experience or belief. This shift does not gain the historian any more evidence for a historical Mara bar Serapion, of course, but it does position the letter as further documentation for a tradition of interchange between Greek and Syriac rhetorical and educational traditions.

\section{THE CHREIA AND ITS USES}

The letter as it stands is in two parts: the letter itself, and a short anecdote about its supposed writer, Mara bar Serapion. The division between the two is stark: the letter, written primarily in the first person and addressed in the second, ends with the words: "And if anyone grieves or worries, I do not counsel him, for there in the life of the whole world he will find us before him."' The anecdote immediately follows, written in the third person, as an account of a conversation between Mara bar Serapion and a companion:

One of his friends asked Mara bar Serapion when he was bound at his side, "By your life, Mara, tell me what laughing-stock appeared to you, that you laughed?" Mara said to him, "I laughed at time, since, although it has not borrowed evil from me, it repays me." 7

This anecdote is in the clearly recognizable form of a rhetorical chreia, a brief narrative, usually concerning a famous historical figure, that ends in a pithy remark or witty gesture. The secondcentury teacher Theon, in his Progymnasmata, lists several types of chreiai, among which are "chreiai that offer an explanation in answer to a question.... For example, 'When he was asked whether the Persian king seemed happy to him, Socrates said: "I can't

${ }^{6} \mathrm{~W}$. Cureton, Spicilegium Syriacum, 48.22-23. Unless otherwise noted, all translations from ancient texts in this essay are my own.

${ }^{7}$ W. Cureton, Spicilegium Syriacum, 48.24-26. 
answer, since I can't know what he thinks of education." " The story of Mara bar Serapion and his laughter seems to fit into this general type; it is difficult to imagine that ancient readers of the anecdote would not have recognized it immediately as an example of the genre. Indeed, as many writers on ancient Greek and Roman education have made clear, the chreia played a significant role even in elementary education in antiquity, being used to teach basic literacy, as well as to inculcate common social and cultural norms. ${ }^{9}$ As Ronald Hock and Edward O'Neil point out, many such chreiai take the form of a saying by a philosophical figure in answer to a question, and closing with a constrastive (usually, in Greek, men...de) response, such as, "When Diogenes was asked why people give to beggars, but not to philosophers, he said, 'Because people expect to become lame or blind, but they never expect to philosophize." 10 This is almost precisely the form of the Mara bar Serapion chreia, with Mara bar Serapion being asked a question and responding with a contrast ("although [time] has not borrowed evil from me, it repays me"). The chreia at the end of the letter thus initially suggests a possible context, as an anecdote typically found in literary schooling.

8 Theon, Progymnasmata, 3.52-54, text in James R. Butts, The Progymnasmata of Theon (Ph.D. dissertation, Claremont Graduate School, 1987).

9 The most useful works on the chreia now available are the two volumes of edited and translated texts on the chreia, with introductions and analyses by Ronald F. Hock and Edward N. O'Neil, The Chreia in Ancient Rhetoric, vol. 1, The Progymnasmata (Atlanta: Scholars Press, 1986), and vol. 2, The Classroom Exercises (Atlanta: Scholars Press, 2002). A third volume is currently being prepared on the chreia in Byzantine commentaries and scholia. Other writers on education who comment helpfully on the uses of the chreia are Teresa Morgan, Literate Education in the Hellenistic and Roman World (Cambridge: Cambridge University Press, 1998), esp. at 186-89; and Raffaella Cribiore, Gymnastics of the Mind: Greek Education in Hellenistic and Roman Egypt (Princeton: Princeton University Press, 2001), 223-24; H. Marrou comments only occasionally on the chreia in his survey of primary and literary education in Greek antiquity: A History of Education in Antiquity (tr. G. Lamb; New York: Sheed and Ward, 1956; reprinted Madison: University of Wisconsin Press, 1982).

${ }^{10}$ R. F. Hock and E. N. O’Neil, Chreia, vol. 2, 16. 
The presence of a typical chreia at the end of the document takes on greater importance if the letter itself is also placed in a context of rhetorical exercises. As is well known, it was common for students of grammar and rhetoric in antiquity to compose themes both about historical figures, and centered on specific historical anecdotes in which these figures played a part. ${ }^{11}$ Perhaps the richest set of examples are those collected in the Suasoriae of the Elder Seneca, in which the embellishment of certain historical situations is standard to many of the exercises, such as the exercises on how to advise Alexander the Great on his battle strategy. ${ }^{12} \mathrm{It}$ was at the same time common for students to compose speeches under the names of various historical figures as an exercise in characterization (prosopopoieia or ethopoieia). ${ }^{13}$ Book 8 of Theon's Progymnasmata is dedicated to prosopopoieia, and includes in its description of this rhetorical practice the creation of speeches attributed to "specific people: for example, what words would Cyrus speak as he moved on the Massagetae, or what would Datis say, after the battle of Marathon, on meeting with the king?" 14 This sort of composition was a familiar exercise for declamation, and Cribiore suggests, given the high rate of survival of examples, that such prosopopoetic writing was likely a favorite school practice..$^{15}$ While I would not argue that the Letter of Mara bar Serapion was composed by a child, or anyone beginning to learn basic rhetorical techniques, I think it is not too much to suggest that it was composed as a prosopopoetic exercise by a writer deeply engaged with the Greek rhetorical tradition, and probably in a pedagogical context. Similarly, the authors of Seneca's Suasoriae were not "beginners," but people to whom demonstration of rhetorical skill was professionally important, and whose work, for that reason, was pedagogically useful.

Following George Kennedy, scholars of ancient education have sometimes placed epistolary composition outside the main

${ }^{11}$ H. Marrou, History of Education, 174; R. Cribiore, Gymnastics, 22830.

12 Suasoriae 1.1-16, text in Michael Winterbottom, The Elder Seneca: Declamations, vol. 2 (Cambridge: Harvard University Press, 1974).

13 Stanley Stowers, Letter-Writing in Greco-Roman Antiquity (Philadelphia: Westminster Press, 1986), 32-33.

${ }^{14}$ Progymnasmata 8.6-8.

${ }^{15}$ R. Cribiore, Gymnastics, 228. 
concentration of formal rhetorical education, suggesting that letterwriting was primarily taught as training for business or civil service. ${ }^{16}$ Others, however, cite the use of model letters in elementary education to argue that letter-writing did form part of the standard curriculum for literacy. ${ }^{17}$ Clearly some teachers, like Theon, ${ }^{18}$ did expect students to write letters as part of their training in ethopoeia or prosopopoeia. Libanius, too, expects his students to have mastered the art of letter-writing. ${ }^{19}$ It would not, then, be especially remarkable to find prosopopoetic letters produced in a school or pedagogical context, even if letter-writing were also covered in other professional training. Combining prosopopoetic writing with paraenetic or hortatory letter-writing would result in something like the example of paraenesis in the epistolary manual of Pseudo-Libanius: "My friend, always become an imitator of virtuous men. For it is better to hear good when imitating good men than to be blamed by everyone when following bad men." 20 Pseudo-Demetrius, in his treatise on Epistolary Types, comes closer to the fictionalizing hortatory letter in his example:

I have presented to you in summary those things for which I am well-respected amongst my subjects. I know then that you, too, can in this way keep the good opinion of your obedient subjects; even though you cannot make many friends, you can be moderate and generous to all. Being such, you will have a good reputation among many, and you will keep your reign tranquil. ${ }^{21}$

This passage is, of course, purely fictive as a moment of royal advice, but the existence of such fictional historicizing exercises should not surprise a reader who is approaching a text with a rhetorical or pedagogical setting in mind.

16 George Kennedy, Greek Rhetoric Under Christian Emperors (Princeton: Princeton University Press, 1983), 70-73.

17 See Abraham J. Malherbe, Ancient Epistolary Theorists (Atlanta: Scholars Press, 1988), 7; and S. Stowers, Letter-Writing, 32-33.

18 Progymnasmata 8.10.

${ }^{19}$ Ep. 777.6; examples are discussed in R. Cribiore (who follows G. Kennedy in placing letter-writing primarily in professional schools), Gymnastics 216-17.

20 Epistolary Styles 52, text in A. J. Malherbe, Ancient Epistolary Theorists, 74.

21 Epistolary Types 11, text in A. J. Malherbe, Ancient Epistolary Theorists, 36. 
Most significantly for the purposes of this paper, it was also common practice for students to read and memorize chreiai, and to use them in composition. At the grammatical level, chreiai were used in exercises on the different declensions, and students were asked to decline chreiai rather repetitively, as in the ars grammatica of Diomedes:

The chreia exercise varies by case as follows: in the nominative singular: Marcus Porcius Cato said that the roots of literature are bitter, but the fruits pleasing. In the genitive: the saying of Marcus Porcius Cato is remembered, that the roots of literature are bitter but the fruits pleasing. In the dative: it pleased Marcus Porcius Cato to say that the roots of literature are bitter, but the fruits pleasing. ${ }^{22}$

A number of preserved Greek school exercises indicate that such declension exercises using chreiai were practiced in schools, and not merely in manuals. ${ }^{23}$ At a more advanced level, rhetoricians adopted the chreia for use in precisely the kind of historicizing composition discussed above. Students would have learned, then, to "expand" chreiai into historical narratives. Theon gives the following brief example:

For example, a concise chreia: Epameinondas, as he was dying childless, said to his friends: "I have left two daughters- the victory at Leuctra and the one at Mantineia." Let us expand like this: Epameinondas, the Theban general, was of course a good man in time of peace, and when war against the Lacedaemonians came to his country, he displayed many outstanding deeds of great courage. As a Boeotarch at Leuctra, he triumphed over the enemy, and while campaigning and fighting for his country, he died at Mantineia. While he was dying of his wounds and his friends were lamenting, among other things, that he was dying childless, he smiled and said: "Stop weeping, friends, for I have left you two immortal daughters: two victories of our country over the Lacedaemonians, the one at Leuctra, who is the older, and the younger, who is just now being born at Mantineia." 24

Notably, this expansion contains several elements in common with the Letter of Mara bar Serapion: it relates itself to actual historical

${ }^{22}$ R. F. Hock and E. N. O’Neil, Chreia, vol. 2, 69.

${ }^{23}$ R. F. Hock and E. N. O'Neil, Chreia, vol. 2, chapter 2 contains a full discussion of these examples.

${ }_{24}$ Progymnasmata 3.226-40, tr. J. R. Butts. 
events; it contains several completely unverifiable-and quite possibly entirely false-historical details; and it has added overt pathos to the concision and understatement of the original chreia. Other educational writers give far more extended examples of chreia elaboration. ${ }^{25}$ Although execution seems to vary, Hock and O'Neil identify the standard elements in chreia elaboration as follows: encomium of the speaker, paraphrase of the chreia, philosophical rationale behind the chreia, argument from the opposite state of affairs, analogy, example, "testimony of the ancients," and a short epilogue. 26 The resulting composition could easily reach the length of the Letter of Mara bar Serapion; comparable examples are found in the work of Libanius, whose teaching in Antioch places him easily within the boundaries of a Greek-Syriac literary milieu.

McVey has raised the possibility that the Letter of Mara bar Serapion is a rhetorical exercise, although she considers it unlikely. ${ }^{27}$ While the letter does not fit exactly the scheme proposed in the rhetorical manuals, I would argue nonetheless that it contains enough of the elements and organization suggested in these pedagogical texts to be taken seriously as a chreia elaboration. The major differences can, I think, be explained by the fact that the writer of the letter has framed his elaboration as a hortatory or paraenetic letter, an exercise in prosopopoieia, rather than more straightforwardly as a third-person account of the chreia and its speaker. ${ }^{28}$ To begin, the letter opens with a brief encomium, typical of chreia elaborations. In this case, the encomium is not of Mara bar Serapion, but is addressed to his son, who is praised for his

${ }^{25}$ See those collected in R. F. Hock and E. N. O’Neil, Chreia, vol. 2, chapter 3 .

${ }^{26}$ R. F. Hock and E. N. O’Neil, Chreia, vol. 2, 83-90. In some texts, various elements are left out or modified, as is typical of differences between educational writers.

${ }^{27}$ K. McVey, "Fresh Look," 272.

28 As Jeffery T. Reed notes, "the flexibility of the epistolary genre allowed for its conflation with other genres": "The Epistle," in $A$ Handbook of Classical Rhetoric in the Hellenistic Period, S. E. Porter, ed. (Leiden: Brill, 1997), 189. Reed also notes (190) that it is more common in the Hellenistic period for pseudonymous letters to follow rhetorical norms than for authentic letters to do so. 
intelligence ("you are very diligent in learning"). ${ }^{29}$ Such substitution of one family member for another also occurs in Pseudo-Nicolaus, Progymnasmata 3, in which Theano, the supposed wife of Pythagoras, is replaced with Pythagoras in the encomiastic section of the elaboration of her chreia. ${ }^{30}$ Further elements of chreia elaboration are also found in the letter: arguments from the opposite case are grouped together at Cureton 45.6-16, which reads in part, "In which possessions will men trust? Or about which things will they say, 'They are abiding?' About an abundance of property, which is stolen? About fortifications, which are plundered? About cities, which are destroyed?" It then offers further examples of the opposite state of affairs by citing exempla of unfortunate figures of the past: "Therefore a man may rejoice in his kingdom like Darius, ... or in his bravery like Achilles, or in his wife like Agamemnon, or in his son like Priam..." Following this section, the letter includes "testimony of the ancients" and examples in the form of further cases from history: "For how did the Athenians profit by the killing of Socrates? They received hunger and death in retribution for it. Or the people of Samos by the burning of Pythagoras? For in one hour their whole land was covered in sand." 31 Further examples are framed, next, as general cases that Mara bar Serapion himself has seen: "But I, my son, have examined those things [...] Evildoers rejoice and the upright are afflicted. The one who has, denies it, and the one who does not have fights to acquire. The poor seek, and the rich conceal, and everyone laughs at his companion." 32 These examples are followed by a concluding exhortation: "For it is not enough to read this matter that thus comes into my mind to write to you, but it should go on into action." 33 Finally, the letter closes with a brief historicizing epilogue placing Mara bar Serapion in a prison setting: "And also here in prison we give thanks to God because we have received the love of many." 34 The presence of all these elements in roughly the correct order according to the norms of chreia

${ }^{29}$ W. Cureton, Spicilegium Syriacum, 43.2.

${ }^{30}$ R. F. Hock and E. N. O’Neil, Chreia, vol. 2, 218.

${ }^{31} \mathrm{~W}$. Cureton, Spicilegium Syriacum, 46.12-14.

${ }^{32}$ W. Cureton, Spicilegium Syriacum, 46.20-47.3.

${ }^{33} \mathrm{~W}$. Cureton, Spicilegium Syriacum, 47.16-17.

34 W. Cureton, Spicilegium Syriacum, 48.7-8. 
elaboration strongly suggests that the writer of the letter is familiar with the rhetorical conventions described above.

There are two key elements that I have not yet discussed, and that have been transformed by the prosopopoetic and hortatory framing of the letter. These are the paraphrase of the chreia and the elaboration of the philosophical rationale behind it. Nearly all of the examples of chreia elaboration include, after the encomium, a paraphrase of the chreia involved. Here, for example, is Libanius' paraphrase of the following chreia:

When asked by someone where he kept his treasures, Alexander pointed to his friends. [...] Paraphrastic. So, having approached him, a certain man said, "O King, I would gladly see your treasures." And it seems to me that he was moved to do this when he saw that an entire nation had just been conquered, and was thinking that the result of this was a great deal of money. What, then, about Alexander? He did not reply immoderately, as if someone had asked him something inappropriate. And he did not order his servants to take the man and lead him around and show him lots of gold, or so many silver talents, or plenty of spoils, but directing the man to look at his friends, he said, "Do not seek any other wealth of Alexander. These are my treasures." 35

The paraphrase here expands the chreia in several ways: first, it sets the chreia within a vaguely historicizing setting by suggesting that Alexander is fresh from a military victory. ${ }^{36}$ There is no evidence in the chreia that this is the setting for the event; it is entirely Libanius' invention. Libanius also adds the suggestion that there are, indeed, piles of gold, silver, and spoils there to be looked at, although Alexander ignores them. Finally, where the chreia does not have Alexander speak at all, Libanius invents a short conversation between Alexander and his inquirer. This kind of expansion appears to be typical of the paraphrases in chreia elaborations. ${ }^{37}$

${ }^{35}$ Libanius, Progymnasmata 3, in R. F. Hock and E. N. O’Neil, Chreia, vol. 2, 140-42.

${ }^{36}$ R. F. Hock and E. N. O’Neil, Chreia vol. 2, 143 n. 281, suggest that the imagined setting may be after Alexander's victory over Darius.

${ }^{37}$ See R. F. Hock and E. N. O’Neil, Chreia, vol. 2, examples collected in chapter 3 . 
The combination of suggested historical detail and invented speech also occurs in the Letter of Mara bar Serapion, a little after the encomium, as one would expect in a chreia elaboration.

For I have heard about our companions, that when they left from Samosata it pained them; and like those who complain of the time, thus they also spoke: "Therefore we are journeying from the house of our people, and we will not return to our city and see our people and receive our gods with honor." 38

There follows a description of the people of Samosata grieving and in exile. Clearly, while the passage is not a direct paraphrase of the chreia, it serves some of the same purposes as the paraphrase: it provides a historical setting for the speaker, and invents dialogue to enliven the scene. Notably, this passage, and the lines following it, have been the lines on which historians have relied most heavily in attempting to date the letter; if it is right to think of the historicizing here as a deliberate rhetorical ploy, the power of this device is still in evidence. ${ }^{39}$ The fact that this passage is not a direct paraphrase of the chreia may, moreover, be explained by the fact that the letter is an exercise in prosopopoeia; Hock and O'Neil list no chreiai that are spoken in the first person, and the move in the letter outside the third person would create difficulty for a writer in summarizing what were purportedly his own actions and sayings. Assuming, then, that the prosopopoeia forbids the writer from paraphrasing directly, in the same way that it forces the encomium to be directed at the addressee rather than the speaker himself, the writer still uses the conventions of paraphrase to suggest a historical context for the speaker and to establish the setting of speaking to one's companions more generally.

After this "paraphrase," there is a short philosophical rationale offered, which reads in part:

But consider this: that to wise men every land is equal, and to good men, in every city there are many fathers and mothers. [...] What, then, do we have to say about the error that is founded in

${ }^{38}$ W. Cureton, Spicilegium Syriacum, 44.6-9.

$39 \mathrm{~W}$. Cureton, Spicilegium Syriacum, pref. xiii-xv, dates it to the late second century; F. Schulthess, "Brief," 379, tentatively to the end of the third century; F. Millar, Roman Near East, 460, suggests the late first century. 
the world? In the world its course is heavy, and in its motions we are shaken like a reed in the wind. ${ }^{40}$

Since the chreia is not directly paraphrased, however, the philosophical rationale for it is also not direct. Rather, the philosophical maxims used throughout the rest of the letter in its paraenetic aspects take up the function of the saying in the chreia, and also provide its philosophical rationale. I turn to these themes next.

\section{Philosophical Themes and Rationales: The CONTENTS OF THE LETTER}

[11] The main theme of the chreia is Mara bar Serapion's philosophical indifference, expressed in his laughter. Secondary elements are: the presence of friends, the prison setting, the troubles of time, and the idea of ownership, as expressed in the metaphor of borrowing and lending. Each of these themes is found in the letter in order in various formulations, so that collectively these too suggest the dependence of the letter-writer on the previous existence of the chreia.

\section{Philosophical Themes}

[12] First, and most obvious in the letter and in the chreia, is the theme of philosophical indifference. The Mara bar Serapion of the chreia has separated himself from his troubles enough to take an ironic position with regard to them. Likewise, the Mara of the letter exhorts his son to the study of philosophy as the only way to separate himself from a variety of troubles. A series of philosophical clichés serve to bolster this exhortation: "Those who busy themselves with philosophy are looking to escape from the distresses of the world." 41 "To wise men every land is equal." 42 "For a man is never loosed from his wisdom as one is from his possessions." 43 The theme of ironic observation and detachment is also persistent: "I wondered at many who cast out their children, and I wondered at others who bring up those who are not their

\footnotetext{
${ }^{40}$ W. Cureton, Spicilegium Syriacum, 44.23-45.2.

${ }^{41}$ W. Cureton, Spicilegium Syriacum, 43.19-20.

42 W. Cureton, Spicilegium Syriacum, 44.23.

${ }^{43}$ W. Cureton, Spicilegium Syriacum, 45.25-26.
} 
own. There are men who acquire property in the world; and I also wondered at the others who inherit what is not their own." 44 These are precisely the sort of nondescript philosophical sentiments about the unpredictability of fate and the need to deal philosophically with loss that school children would have learned and copied as maxims in any Hellenistic or Roman school setting, for example, in the sayings of Menander, or the appearance of such lines as, "To the wise man, every land is home," or even, "Whoever thinks to fare well through phronesis: it is useless, for everything in life comes about not through intellect, but through chance." 45 Clearly one of the main concerns of educational literature is the teaching of such commonplaces, and the reasons behind them. In this respect, the Letter of Mara bar Serapion breaks no new ground.

Indeed, as a concrete development of the idea of indifference, the writer of the letter focuses at length on the idea of the wise man's attitude toward possessions. In the chreia, this theme is expressed in the metaphor of borrowing and lending; in the letter, its expression is much more literal. Again, the sentiments found in the letter are for the most part unexceptional: "And let not ownership subdue you, which many hunger after, and let it not entice your eye to desire riches, something which does not endure." 46 Or, again, "all of these possessions which are seen by you in the world, like one who exists for a little time, like a dream they are loosed." 47 "For I have seen that when there are many goods, so also distresses are met. And just as luxuries are brought, so also are griefs gathered. And [where] properties are great, there the years of bitterness are many." 48 The philosophical depth of these exhortations is minimal, yet they reflect a basic exposure to the philosophical parlance of antiquity. They recur in the

${ }^{44}$ W. Cureton, Spicilegium Syriacum, 45.2-4. K. McVey, "Fresh Look," 271 , suggests that the first part of this remark is a condemnation of the exposure of children, an argument that I discuss below.

${ }^{45}$ Quoted in T. Morgan, Literate Education, 133. NB that Morgan also describes maxims on the appropriateness of properly seeking wealth (125-27); it is important to remember that these maxims are not strictly meant as a coherent philosophical program, but as an induction into commonly held cultural values.

${ }^{46} \mathrm{~W}$. Cureton, Spicilegium Syriacum, 43.22-33.

47 W. Cureton, Spicilegium Syriacum, 43.24-44.1.

${ }^{48}$ W. Cureton, Spicilegium Syriacum, 45.27-46.2. 
elaborations of chreiai, especially in the sections devoted to the "philosophical rationale" of the chreia. For example, one chreia elaboration preserved in the work of Doxapatres explains this chreia as follows:

The saying of Aphthonius the rhetor is remembered, who said, "It is grievous to lose what has already been experienced." [...] The rationale: Since everyone prefers what is known to what is unknown, and since everything whose usefulness is known is considered better, he judged that the loss of these things would be very painful....49

In the case of its passages on the transience of possessions, the letter does reveal a moral stance similar to Stoicism, but this devaluing of material wealth was also a commonplace in NeoPlatonic thought and Pythagoreanism, ${ }^{50}$ not to mention ancient Near Eastern wisdom literature, and, as we have seen, basic literate education in the Hellenistic and Roman world.

More specifically, the chreia suggests that Mara bar Serapion's detachment is so great that he can laugh at his situation even when "bound." Theon preserves a similar chreia about Socrates: "The philosopher Socrates, when a certain Apollodorus, an acquaintance, said to him, 'The Athenians have unjustly sentenced you to death,' responded, laughing, 'But did you want them to do it justly?"'51 In the letter, Mara bar Serapion's observations and his ironic surprise find their counterpart in the laughter with which the world greets the wise man: "The poor seek and the rich conceal, and everyone laughs at his companion... They rejoice in evil affairs and they spurn the one who speaks the truth. A man marvels, therefore, when the world wears him out in scorn...."52 The presence of this scornful laughter alongside Mara's notes on human inconsistency recalls the two different kinds of laughter in the chreia: first, the "laughing-stock" that Mara's friend sees nowhere in evidence, and second, the philosophical—and by ordinary standards unexpected-laughter of Mara bar Serapion himself. In the letter, the two types of laughter are developed into the full-blown themes of philosophical indifference and irony (the laughter of Mara bar

\footnotetext{
${ }^{49}$ R. F. Hock and E. N. O’Neil, Chreia vol. 2, 244.

${ }^{50}$ K. McVey, "Fresh Look," 261.

${ }^{51}$ R. F. Hock and E. N. O’Neil, Chreia, vol. 1, 90.

52 W. Cureton, Spicilegium Syriacum, 47.2-6.
} 
Serapion), and the world's rejection of the sage (expected laughter at a laughing-stock). Neither theme can claim either originality or development in the letter, but both give evidence of a basic grounding in ancient philosophical tropes in use in rhetorical training. On the assumption that the letter is secondary to the chreia, the unremarkableness of all of these sentiments is fairly easy to understand. If the author of the letter was more concerned with drawing out the themes implicit in the chreia than in advancing their philosophical development, s/he has done an admirable job. Moreover, in hortatory or paraenetic letters, it was not always considered good form to submit original philosophical insights. The epistolary manual of Pseudo-Libanius contains the following advice on writing paraenetic letters: "[P]araenesis is hortatory speech that does not admit of a counter-statement, for example, if someone should say that we must honor the divine. For nobody contradicts this exhortation were he not mad to begin with." 53 Thus the very commonness of the letter-writer's expressions lends them a certain rhetorical force.

Perhaps the most interesting aspect of the letter s the writer's use of the figure of time ( $q a b n \hat{a})$. Here the ambivalence in the letterwriter's interpretation of the chreia becomes obvious. "Time" in the chreia is personified to ironic effect, and seems to mean approximately the same thing as "circumstance": "I laughed at time, since, although it has not borrowed evil from me, it repays me." In the letter, "time" is an ambiguous figure. Friedrich Schulthess supposed that "time" in the letter was an expression of the Stoic concept of "fate," 54 but as McVey points out, this is a strained and otherwise unattested translation. ${ }^{55}$ I would argue that the philosophical generalities in the letter also weigh against a strict technical interpretation of the term. Cureton seems to see "time" as personified at some points in the letter ("the Time forbade us to complete those things;" 56 "that dominion which the Time has assigned to us" 57 ), but not at others ("such men as are called to discipline seek to disentangle themselves from the struggle of the

${ }^{53}$ Epistolary styles 5, tr. A. J. Malherbe, Ancient Epistolary Theorists, 69.

${ }^{54}$ F. Schulthess, "Brief," 383.

${ }^{55} \mathrm{~K} . \mathrm{McV}$ ey, "Fresh Look," 262.

${ }^{56}$ W. Cureton, Spicilegium Syriacum, 75.30.

${ }^{57} \mathrm{~W}$. Cureton, Spicilegium Syriacum, 76.7-8. 
time;" 58 "they are the ups and downs of the times"59). The ambiguity is understandable, however, if the author of the letter is seeking to conform both to the personification in the chreia and to a more prosaic use of the word. The personification of "time" in the anecdote is striking, and could be put to good rhetorical effect, but would be difficult to sustain over an extended composition. The repeated use of the word "time" in the letter reflects the centrality of "time" in the chreia, but its ambiguity in the letter seems to be a result of the problems inherent in expanding a concise witticism into a serious treatise. Theon's chreia of Epameinondas, quoted earlier, comes to mind: here the Theban general's victories are personified as his daughters, but in the expanded chreia the victories are described in both everyday terms and in personified terms. The result is perhaps more labored than the original, with the change from "I have left two daughters- the victory at Leuctra and the one at Mantineia" to "Stop weeping friends, for I have left you two immortal daughters: two victories of our country over the Lacedaemonians, the one at Leuctra, who is the older, and the younger, who is just now being born at Mantineia." Given the manner in which the writer of the Letter of Mara bar Serapion follows other conventions of chreia elaboration, it is perhaps best to see the figure of time as ambiguous by virtue of the difficulty of chreia expansion rather than because of a complex philosophical agenda.

\section{Historical Themes}

The presence of both friends and troubles is another obvious theme in the letter and chreia, and it is through examination of the "hardship" of Roman military action described in the letter that scholars have generally attempted to place the letter in a specific historical context. ${ }^{60}$ Yet these examinations have been singularly inconclusive. The references in the letter to a Roman conquest of Samosata suggest, at first glance, three different possible contexts for the letter: the Roman takeover of Commagene in the late first century, the war between Rome and Parthia in the mid-second century, and the conflict between the emperor Valerian and the

\footnotetext{
${ }^{58}$ W. Cureton, Spicilegium Syriacum, 70.23-24.

${ }^{59}$ W. Cureton, Spicilegium Syriacum, 71.5.

${ }^{60}$ See n. 37 , above.
} 
Persian Shapur I in the mid-third century. Unfortunately, the flight to Seleucia and the imprisonment of residents of Samosata described in the letter do not find corroboration in accounts of any of these three conflicts. ${ }^{61}$ Fergus Millar has suggested that a late first century date may be most probable for the letter, but acknowledges that the assumption of any such strict historicity in the letter is problematic. ${ }^{22}$ Given the difficulty in matching the circumstances described in the letter to any known Roman conquest of Samosata, however, it is worth considering more seriously the possibility that the letter-writer is not describing actual events at first hand, or at all. The muddled description of Mara bar Serapion's troubles could more easily have arisen from the clues given in the chreia, namely, that Mara is imprisoned with certain companions, and that the times are bad. The detail of Roman conquest would then be a rhetorical flourish based on the knowledge that the Romans had, at some point in the past, conquered Samosata. The parallels with Theon's "expanded" chreia are here apt: the student of rhetoric is to give the anecdote a lively historical setting, adding whatever details seem most plausible or vivid. Details of Mara bar Serapion's capture by the Romans lend the letter both vividness and a certain pathos which the chreia itself lacks. Likewise Libanius' elaboration of the Alexander chreia: the chreia is given a setting "historical enough" to tempt scholarly identification (Hock and O'Neil suggest Alexander's victory at Gaugamela), ${ }^{63}$ but there is no need for this account to be read as accurate. Indeed given the fact that the same chreia could be attributed to various speakers, ${ }^{64}$ some caution in reading them as the basis for historical accounts must be maintained.

There is one important historicizing element found in the letter that is absent in the chreia: the presence of children, both the children mentioned in the description of the exiles, and Mara bar Serapion's son specifically. ${ }^{65}$ Yet the children in the letter are easily explained by the genre of the text. The letter is an exhortation to the philosophic life, and such exhortations were traditionally given

${ }^{61}$ See K. McVey, "Fresh Look," 258-60.

${ }^{62}$ F. Millar, Roman Near East, 460-62.

${ }^{63}$ R. F. Hock and E. N. O’Neil, Chreia, vol. 2, 143 n. 281.

${ }^{64}$ R. F. Hock and E. N. O’Neil, Chreia, vol. 1, 309, 315-16, 325-26.

${ }^{65} \mathrm{~F}$. Schulthess suggests a situation in which Mara bar Serapion and his son were separated during the leaving of Samosata: "Brief," 377-78. 
the form of advice from an older man to a younger. ${ }^{66}$ The most famous example of the genre is probably Seneca's set of letters to Lucilius, advising the young (and possibly fictitious) ${ }^{67}$ man on the proper method of undertaking the philosophic life. However, such letters were also commonly in the form of advice given from father to son; the trope of father-to-son exhortation is a common one in both Roman didactic and Near Eastern wisdom literature. ${ }^{68}$ In literature on the chreia, too, the theme of proper upbringing of the young is prominent: one of the most often-quoted chreiai is that of Diogenes: "When he saw a boy misbehaving, Diogenes struck the boy's pedagogue." ${ }^{69}$ Both Libanius and Pseudo-Nicolaus elaborate this chreia with appeals to parents' concern that their children be taught proper behavior by their pedagogues, acknowledging the trope of the parent as arbiter of correct education. ${ }^{70}$ The letterwriter is thus able to frame Mara bar Serapion's letter in a highly traditional manner and then use this framework to include another common philosophical complaint: that children, good and bad alike, are most often a grief to their parents. ${ }^{71}$ Thus the act of expanding the chreia into a historical document and philosophically hortatory letter using the figures of sons and children allows the letter-writer to conform even more closely to traditional GrecoRoman rhetorical norms.

The Letter of Mara bar Serapion seems to fit in with the general pattern of chreia elaboration, with paraenesis added and certain elements of the chreia elaboration form modified to suit the genre of the prosopopoetic letter. A schematic division of the letter into its different rhetorical components would then look something like this:

Rhetorical Components

encomium

\section{Cureton}

$43.1-5$

${ }^{66}$ Cf. S. Stowers, Letter-Writing, 39.

${ }^{67}$ S. Stowers, Letter-Writing, 40.

${ }^{68}$ For a detailed discussion of the Roman tradition, see Fannie J. LeMoine, "Parental Gifts: Father-Son Dedications and Dialogues in Roman Didactic Literature," Illinois Classical Studies XVI (1991): 337-66.

${ }^{69}$ R. F. Hock and E. N. O'Neil, Chreia vol. 1, 316, cite it as the most frequently occurring chreia in their set of texts.

${ }^{70}$ R. F. Hock and E. N. O’Neil, Chreia, vol. 2, 158-60, 212-14.

${ }^{71} \mathrm{~W}$. Cureton, Spicilegium Syriacum, 44.3-6. 


$\begin{array}{ll}\text { Rhetorical Components } & \text { Cureton } \\ \text { paraenesis } & 43.5-44.6 \\ \text { paraphrase/historicization } & 44.6-20 \\ \text { philosophical rationale } & 44.20-45.5 \\ \text { argument from the opposite } & 45.6-17 \\ \text { further paraenesis } & 45.18-46.9 \\ \text { testimony of the ancients/exempla } & 46.10-47.16 \\ \text { further paraenesis } & 47.16-48.7 \\ \text { epilogue } & 48.7-23 \\ \text { followed by the original chreia } & 48.24-26\end{array}$

In comparison with Hock and O'Neil's list of elements common to the chreia elaboration (encomium, paraphrase, philosophical rationale, argument from the opposite, analogy, example, testimony of the ancients, epilogue), the similarities are very clear.

\section{CONCLUSION: SYRIA, GREEK EDUCATION, AND CHRISTIANITY}

[19] The idea that the Letter of Mara bar Serapion is deeply indebted to Greek rhetorical traditions, and may not reveal much as an eyewitness account of a Roman victory, has of course arisen in other work on the letter, although the work's specific status as a chreia elaboration has not, until now, been explored..$^{72} \mathrm{McVey}$ has argued that the letter conforms in many respects to stock philosophical writing in antiquity, and that extrapolating a concrete historical setting or context from the letter is difficult, not to say impossible. Specifying that the letter is a chreia elaboration would, I think, both reinforce and explain this difficulty: while it acknowledges that "Mara bar Serapion" may well have been a recognizable historical figure to the readers of the chreia, it gives modern readers no more actual historical information about him than Libanius' elaboration of the Alexander chreia gives us about Alexander. McVey argues further that the writer of the letter can nonetheless be identified as a Christian writer of the fourth century,

${ }^{72}$ F. Millar, Roman Near East, 460-61, acknowledges that the letter is problematic but attempts to date it to the first century nonetheless, on the assumption that it is a product of the Roman victory at Commagene. 
on the strength of two passages: one that apparently connects the dispersion of the Jews to the death of their "wise king," and another that describes people as "casting out" their children, a passage that McVey takes to be a reference to (and condemnation of) the exposure of infants. ${ }^{73}$ Her conclusion is that the writer is a Christian apologist posing as a pagan intellectual in order to support Christian supersessionist and moral claims. Here, too, however, the identification of the letter as a chreia elaboration should complicate the drawing of such straightforward conclusions from these two passages.

To take the second passage first, as the simpler case: the lines in question read as follows: "For I wondered at many who cast out their children, and I was amazed at others who bring up those who are not their own. There are men who acquire property in the world; and I also was amazed at the others who inherit what is not their own." 74 If we read the letter as a rhetorical exercise, it is easy to connect this passage to such texts as the Controversiae of the Elder Seneca, in which children are frequently lost, kidnapped, disinherited, or otherwise misplaced through often spectacular turns of fortune. ${ }^{75}$ In a slightly more subdued Greek rhetorical context, the passage is reminiscent of another chreia attributed to Diogenes: "The Cynic philosopher Diogenes, when he saw an illegitimate child throwing stones, said, 'Stop, child! You might hit your father without knowing it." 76 The point is more about human ignorance and turns of fortune than simply about the ethics of stone-throwing. I would suggest that the passage in the Letter of Mara bar Serapion takes up this trope, not to condemn child exposure per se, but as a comment on the unpredictability of human affairs and the resultant need for detachment. As the letter elsewhere suggests, "glory, that vanity that fills the life of men, do not reckon it among those things that make us happy: quickly it does us harm, especially in the birth of beloved sons." 77 It is hard

${ }^{73}$ K. McVey, "Fresh Look," 267-71.

74 W. Cureton, Spicilegium Syriacum, 45.2-4.

${ }^{75}$ E.g., Seneca, Controversiae 7.1.1, "The man who was released by his son, the pirate chief;" 7.3.1, "The thrice-disinherited son caught pounding up poison;" 7.4.1, “The blind mother who would not let her son go," text and tr. in M. Winterbottom, Elder Seneca.

${ }^{76}$ R. F. Hock and E. N. O’Neil, Chreia, vol. 1, 317.

77 W. Cureton, Spicilegium Syriacum, 44.2-4. 
to read this as an unmixed endorsement of child-rearing. The question of child exposure, then, taken in a rhetorical context, does not allow for a simple identification of the letter with any specifically Christian moral claims.

It is harder to interpret the passage about the dispersion of the Jews and about their "wise king." This is partly because there is a crucial verb missing in the passage, and partly because, as we have seen, the genre of chreia elaboration tends to historicize in extremely vague ways. Again, it is worth quoting the passage in full; it occurs in the section of the letter that, following the conventions of chreia elaboration, combines exempla and "testimony of the ancients" to support its argument:

For what did the Athenians profit by the killing of Socrates? They received hunger and death in retribution for it. Or the people of Samos by the burning of Pythagoras? For in one hour their whole land was covered in sand. Or the Jews, of their wise king? For from that very time their kingdom was taken away. For God justly made retribution for the wisdom of these three, for the Athenians died hungry and the people of Samos were irreparably covered by the sea, and the Jews were destroyed and persecuted out of their kingdom, and are dispersed throughout every land. Socrates is not dead, because of Plato, nor Pythagoras, because of the statue of Hera, nor the wise king, because of the new laws that he established. ${ }^{78}$

There is, unfortunately, no clarifying verb in the question, "Or the Jews, of their wise king?" It is reasonable to suppose that, given the context, the reader should supply a phrase like, "by the death [sc. of their wise king]," and in fact this is what Cureton does in his translation, ${ }^{79}$ but it is significant that Jesus is not actually named in the text, nor is the crucifixion specified. I do not mean to suggest that the writer here cannot have a Christian apologetic argument in mind, and I think it is more than reasonable to suppose that the

${ }^{78}$ W. Cureton, Spicilegium Syriacum, 46.12-20.

79 W. Cureton, Spicilegium Syriacum, 73.35-36. F. Schulthess, "Brief," 371, likewise supplies "by the killing [sc. of their wise king]" here. It may be going too far to supply "by the rejection/crucifixion?," as K. McVey does ("Fresh Look," 264), especially since "crucifixion" would presumably remove all doubt that the "wise king" should be identified with Jesus, who is after all never named in the text. 
"wise king" here is meant to be a reference to Jesus..$^{80}$ This has been the general consensus of scholars working on the letter since Cureton. ${ }^{81}$

The vagueness of the reference is, however, important. Cureton suggests that it is due to the early date of the letter, and that the writer was prudently avoiding a mention of Jesus in order to remain safe during a period in which Christians were persecuted. ${ }^{82}$ If the letter is a chreia elaboration, however, there is no need to suppose that the lack of specificity is so coherently motivated. As McVey notes, the reference to Pythagoras in the same passage is also problematic, in that the writer conflates Pythagoras the philosopher with Pythagoras the sculptor, also of Samos, who, according to Diogenes Laertius, lived at about the same time. ${ }^{83}$ The appeal in both cases, then, is not necessarily to a Pythagoras or to a "wise king" the specific details of whose identity are vital to the argument. Rather, the appeal is to a more general "antiquity" populated by generic wise figures who are persecuted. To return, briefly, to Libanius' elaboration of the chreia on Alexander and his friends, Libanius offers the examples of Orestes and Pylades and of Achilles and Patroclus as support for his argument that friends, are, indeed, treasures. ${ }^{84}$ These examples tell us no more than that these legendary figures were recognizable as "friends" in Greek cultural discourse. They do not entail that Libanius endorsed a return to Homeric military or religious ideals. Indeed, despite his devotion to traditional Greek gods, it seems clear that Libanius did not, for example, follow Julian the Apostate in any extreme religious nostalgia. ${ }^{85}$ It is plausible then that by the time the Letter of Mara bar Serapion was written, some form of the

80 NB however that F. Millar, Roman Near East, 461, considers Solomon an equally likely possibility.

81 W. Cureton, Spicilegium Syriacum, pref. xiii; F. Schulthess, "Brief," 379; Drijvers, "Hatra," does not mention the passage specifically, but places the letter in a Christian milieu; K. McVey, "Fresh Look," $263 \mathrm{ff}$.

82 W. Cureton, Spicilegium Syriacum, pref. xiii-xiv.

${ }^{83}$ K. McVey, "Fresh Look," 270; Diog. Laer. V. Pyth. 25, text and tr. in R. D. Hicks, Diogenes Laertius: Lives of Eminent Philosophers (Harvard: Cambridge University Press, 1925).

${ }^{84}$ R. F. Hock and E. N. O’Neil, Chreia, vol. 2, 152.

85 Cf. Polymnia Athanassiadi, Julian and Hellenism (Oxford: Oxford University Press, 1981), 126-27, 206-7. 
anti-Jewish argument that the death of Jesus, or of a "wise king," was the reason for the dispersal of the Jews was current in Syriac thought. This would support McVey's contention that the letter may date from around the fourth century or later, when the argument is prominent in Syriac Christian sources. It does not, however, entail that the writer of the letter had a particular theological interest in promoting this argument. On the contrary, Bowersock's work on the long period of coexistence between "paganism" and Christianity in Syria seems well supported by a letter that places Socrates, Pythagoras, and Jesus (or a wise Jewish king) in precisely the same group, namely, persecuted wise men. ${ }^{86}$ If, as Bowersock has argued, Hellenism, Christianity and local cult could thrive in coexistence in Syria, it would be prudent to avoid the conclusion that any familiarity with Christian arguments implies a Christian affiliation. The composition of an originally Greek type of rhetorical exercise in Syriac should, instead, make clear the vast range of possibilities for cultural and narrative interchange in such a text. Rather than privileging one narrative over the others, it may be better to use this text to question the likelihood that cultural and religious affiliations were routinely seen as exclusive in the late ancient Near East.

The removal of the Letter of Mara bar Serapion to his Son from a concrete historical context poses certain problems for the historian of Syrian-Roman relations in the first centuries CE. The letter's placement in a far more traditional rhetorical context, however, opens up new possibilities for the study of early Syriac literature and the history of education in the provinces of the Roman Empire. Although the date of the letter, on this reading, remains elusive, the use of Greek and Roman rhetorical forms in Syriac prose composition suggests a high degree of cultural exchange between Syriac speakers and their imperial neighbors. Notably, the codex in which the Letter of Mara bar Serapion is found also contains several translations of Greek philosophical and educational works, among them sententiae of Menander, Isocrates' paraenetic speech to

86 Glen W. Bowersock, Hellenism in Late Antiquity (Ann Arbor: University of Michigan Press, 1990), chapter 3. See also H. J. W. Drijvers, "The Persistence of Pagan Cults in Christian Syria," in East of Byzantium: Syria and Armenia in the Formative Period, ed. Nina G. Garsoïan et al. (Washington: Dumbarton Oaks, 1982), 35-43. Drijvers has a less optimistic view about this coexistence, but acknowledges that it did occur. 
Demonicus, maxims attributed to Theano and to Pythagoras, works of Aristotle, and Porphyry's Isagoge, as well as Greekinfluenced works such as the Book of the Laws of the Countries. ${ }^{87}$ If Cureton is correct in dating the codex to the sixth or seventh century, it would also have been produced during a prolific period in the translation of Greek works into Syriac. ${ }^{88}$ The Letter of Mara bar Serapion, following Brock's general narrative of progressive Syriac assimilation to Greek culture over the fourth to the eighth century, ${ }^{89}$ may be later than the fourth century. Along with the Greek translations in the codex are a large number of works by the late fifth-/early sixth-century Syriac philosopher Sergius of Resh'aina, commentator on Aristotle and translator of Galen. ${ }^{90} \mathrm{~A}$ similar move toward Syriac cultural adoption of Greek figures is evident in the number of Greek cultural icons used in the letter: Socrates, Plato, Pythagoras, Achilles, Priam, and Agamemnon, to name only a few. ${ }^{91}$ This prominence of Greek rhetoric and literary

${ }^{87}$ See William Wright, Catalogue of the Syriac Manuscripts in the British Museum, vol. 3 (London, 1872, repr. Piscataway: Gorgias Press, 1990), 1154-60.

${ }^{88}$ See Sebastian Brock, "From Antagonism to Assimilation: Syriac Attitudes to Greek Learning," in East of Byzantium: Syria and Armenia in the Formative Period, ed. Nina G. Garsoïan, et al. (Washington: Dumbarton Oaks, 1982), 17-34; for the position of these translations in a larger narrative of transmission of Greek literature into Syriac and Arabic, see S. Brock, "Greek into Syriac and Syriac into Greek," Journal of the Syriac Academy III. Baghdad (1977): 1-17; reprinted in S. Brock, Syriac Perspectives on Late Antiquity (London: Variorum, 1984); and D. Gutas, Greek Thought, Arabic Culture: The Graeco-Arabic Translation Movement in Baghdad and Early 'Abbasid Society (London: Routledge, 1998), 20-23.

${ }^{89}$ S. Brock, "From Antagonism," 19-25.

${ }^{90}$ W. Wright, Catalogue, 1154-58; cf. S. Brock, "From Antagonism," 21.

${ }^{91}$ On the other hand, the number of Greek loan-words in the letter is small; the names of Greek literary and cultural figures are easily the most prominent. Brock argues for an increasing use of Greek loan-words as assimilation occurs, especially in translations (S. Brock, "From Antagonism," 18; see also his "Aspects of Translation Technique in Antiquity," Greek, Roman and Byzantine Studies 20 [1979]: 69-87) and "Some Aspects of Greek Words in Syriac," in Synkeretismus im syrischpersischen Kulturgebiet, ed. A. Dietrich (Göttingen: Vandenhoeck \& Ruprecht; reprinted in Syriac Perspectives in Late Antiquity). It may be, 
culture in the letter is even more clearly recognizable once the letter is properly understood to be a chreia elaboration.

The Letter of Mara bar Serapion is thus a document of both limited and important historical use. While it tells us little about the political relationship between the Roman Empire and late ancient Syria, it nonetheless usefully illustrates the intersection of Greek literary forms and Syriac literary practice. The writer who posed as Mara bar Serapion for the purposes of this letter should alert students of Syriac literature and Christianity, not so much to the need for a philosophical outlook on life, as to the need to approach ancient Syria as an active participant in the culture of the broader Mediterranean world.

\section{BIBLIOGRAPHY}

Athanassiadi, Polymnia. Julian and Hellenism. Oxford: Oxford University Press, 1981.

Bowersock, Glen W. Hellenism in Late Antiquity. Ann Arbor: University of Michigan Press, 1990.

Brock, Sebastian. "Aspects of Translation Technique in Antiquity." Greek, Roman and Byzantine Studies 20 (1979): 69-87. Reprinted in idem, Syriac Perspectives on Late Antiquity. London: Variorum, 1984.

-. "From Antagonism to Assimilation: Syriac Attitudes to Greek Learning." In East of Byzantium: Syria and Armenia in the Formative Period, ed. Nina G. Garsoïan, et al. Washington: Dumbarton Oaks, 1982, 17-34. Reprinted in Brock, Syriac Perspectives on Late Antiquity.

-. "Greek and Syriac in Late Antique Syria." In Literacy and Power in the Ancient World, ed. Alan K. Bowman and Greg Woolf. Cambridge: Cambridge University Press, 1991, 149-60.

—. "Greek into Syriac and Syriac into Greek." Journal of the Syriac Academy III. (1979): 1-17. Reprinted in Brock, Syriac Perspectives on Late Antiquity.

however, that the use of loan-words in a rhetorical exercise would have been considered "bad form," as it often was in Latin and Greek practice. As Brock has elsewhere suggested, in some bilingual contexts Syriac would have been considered a language of greater literary prestige than Greek, which might also have inclined the author to avoid loan-words: S. Brock, "Greek and Syriac in Late Antique Syria," in Literacy and Power in the Ancient World, ed. Alan K. Bowman and Greg Woolf (Cambridge: Cambridge University Press, 1991), 149-60. 
—. "Some Aspects of Greek Words in Syriac." In Synkretismus im syrischpersischen Kulturgebiet, ed. A. Dietrich. Göttingen: Vandenhoeck \& Ruprecht. Reprinted in Brock, Syriac Perspectives on Late Antiquity.

Butts, James R. The Progymnasmata of Theon. Ph.D. dissertation, Claremont Graduate School, 1987.

Cribiore, Raffaella. Gymnastics of the Mind: Greek. Education in Hellenistic and Roman Egypt. Princeton: Princeton University Press, 2001.

Cureton, William. Spicilegium Syriacum. London: Francis and John Rivington, 1855.

Diogenes Laertius. Life of Pythagoras. Text and translation in R. D. Hicks, Diogenes Laertius: Lives of Eminent Pbilosophers. Harvard: Cambridge University Press, 1925.

Drijvers, H. J. W. "Hatra, Palmyra und Edessa: Die Städte der syrischmesopotamischen Wüste in politischer, kulturgeschichtlicher und religionsgeschichtlicher Beleuchtung." $A N R W$ II.8 (1977): 806-901.

- . "The Persistence of Pagan Cults and Practices in Christian Syria." In East of Byzantium: Syria and Armenia in the Formative Period, ed. Nina G. Garsoïan, et al. Washington: Dumbarton Oaks, 1982, $35-43$.

Gutas, Dimitri. Greek Thought, Arabic Culture: The Graeco-Arabic Translation Movement in Bagbdad and Early 'Abbasid Society. London: Routledge, 1998.

Hock, Ronald F., and Edward N. O'Neil, The Chreia in Ancient Rhetoric. Vol. 1: The Progymnasmata. Vol. 2: The Classroom Exercises. Atlanta: Scholars Press, 1986, 2002.

Kennedy, George. Greek Rhetoric under Cbristian Emperors. Princeton: Princeton University Press, 1983.

LeMoine, Fannie J. "Parental Gifts: Father-Son Dedications and Dialogues in Roman Didactic Literature." Illinois Classical Studies XVI (1991): 337-66.

Malherbe, Abraham J. Ancient Epistolary Theorists. Atlanta: Scholars Press, 1988.

Marrou, Henri-Irénée. A History of Education in Antiquity. Tr. G. Lamb; New York: Sheed and Ward, 1956; reprinted Madison: University of Wisconsin Press, 1982.

McVey, Kathleen E. "A Fresh Look at the Letter of Mara Bar Serapion to his Son.” V. Symposium Syriacum 1988, ed. R. Lavenant, Orientalia Christiana Analecta 236 (1990): 257-72.

Millar, Fergus. The Roman Near East 31 BC-AD 337. Cambridge: Harvard University Press, 1993.

Morgan, Teresa. Literate Education in the Hellenistic and Roman World. Cambridge: Cambridge University Press, 1998.

Ramelli, Ilaria. "La lettera di Mara bar Serapion." Stylos 13 (2004): 77-104. 
Reed, Jeffrey T. "The Epistle." In A Handbook of Classical Rhetoric in the Hellenistic Period, ed. S. E. Porter. Leiden: Brill, 1997, 171-93.

Schulthess, Friedrich. "Der Brief des Mara bar Sarapion." Zeitschrift der deutschen morgenländischen Gesellschaft 51 (1897): 365-91.

Stowers, Stanley K. Letter-Writing in Greco-Roman Antiquity. Philadelphia: Westminster Press, 1986.

Winterbottom, Michael. The Elder Seneca: Declamations. Vol. 2. Cambridge: Harvard University Press, 1974.

Wright, William. Catalogue of the Syriac Manuscripts in the British Museum. Vol. 3. Originally published in London, 1872; repr. Piscataway: Gorgias Press, 1990. 
